\title{
The Model of Intellectual Capital based Information Technology and Its Implication on Employees Performance.
}

\author{
(Case study at Indonesian Aerospace Industries,Ltd)
}

\author{
Odang Kusmayadi ${ }^{1}$, Danny Ramdani $\square^{2}$ \\ ${ }^{1}$ Economics and Business Faculty of Singaperbangsa Karawang University Indonesia \\ odang.kusmayadi@feb.unsika .ac.id \\ ${ }^{2}$ Economics and Business Faculty of Singaperbangsa Karawang University Indonesia \\ danny.ramdani@feb.unsika.ac.id \\ Correspondence Author
}

Article History: Received: 11 January 2021; Accepted: 27 February 2021; Published online: 5 April 2021

\begin{abstract}
This research focused on higher of job rejection result and low of coordination among unit in problem solving of all the projects which is tend to decline of employees performance. The main issues discussed in this reseach is factors influence it, namely human procurement, development and intellectual capital based information technology. The research aims to analyze, describe and test the impact of human procurement, development on intellectual capital and its implication on employees performance at Indonesian Aerospace,Ltd. The research used was descriptive and explanatory survey method, so the research attempts to collect, present, analyze, and test hypotheses, to make a consclusions were used Structural Equation Model (SEM) approach. The design of study is a survey reseach, the unit analysis selected were core knowledge worker with a sample size of 303 from 1245 employees, based on Slovin's formula. The results indicated that human procurement, development have a simultaneously positive and significant effect on intellectual capital based information technology, and human procurement, development are either partialy or simultaneously have a positive and significant effect on employees performance level throught intellectual capital based information technology. The findings are:(1) human procurement indicates low contribution on either intellectual capital based information technology or employees performance, the highest score of human procurement dimension is selection and the lowest is recruitment dimension. 2) human development indicates low contribution on either intellectual capital or employees performance, the highest score of human development dimension is education and the lowest is training dimension (3) intellectual capital based information technology indicates moderate scores on employees performance level, the highest score of intellectual capital dimension is social capital and the lowest is structure capital dimension. (4) the highest score size of employees performance dimension based on employees perception is goal and the lowest is motive dimension.
\end{abstract}

Keyword: Human Procurement, Development, Intellectual Capital, Information Technology, Performance.

\section{Introduction}

The utilizing of high technology and safety level among transportations nowdays is air transportation. In world flight recently needs two aspects namely tools and human resources. The most important aspect of both is human resources, because without them, the equipments or tools are useless operated. Many companies have recently capabilities to operate advance technology in running their business, but just a few of companies could bring into reality by utilizing technolofy in an optimmal fashion, one of its causal factors is lack available of human resources capablities in mastering technology. The achievement of any companies in business world lie recently with their quality of human resources. Therefore, organizations should have a capabilities to recruit, select and replace also to manage human resources correctly. According to Noe ( 2013) "Recruitment is one of organization activities by purpose to identify and to get potential employee. Human procurement as a human resource management function is one of the activities that impact critically on the performance of an organization. While it is understood and accepted that poor procurement decisions continue to affect employee performance which in turn affects organizational performance and limits goal achievement.

Bontis (2004) said that the organization would have a successful, if it has human resources with characteristic as: valuable, rare, has no perfect imitation, unsubstitutable by any other resource by the competitors, and it will be a sustaining competitive advantage for organization. The study conducted by LBA Consulting Group for 25 years toward the success and failure of some organizations, reseach finding indicated, there are six factors should be fulfilled by organization, are : Culture with performance oriented, low of employees turn over, high of employees satisfaction level, good quality of human resources cadres, effectiveness of investment employees selection process and performance with competencies based as a success factor.

Some studies already done with relation to human procurement ( recruitment and selection) practices and how it affects employees performance in organizations. Zheng and Hong (2006) and Croucher (2008) point out 
that there is a positive and significant relationship between human procurement ( recruitment and selection) and performance of a firm. Sang (2005) also discovered a positive association between human procurement ( recruitment and selection) recruitment and business performance. Ichniowski and Shaw (1999), Katou and Budhwar (2006), and Wright and Boswell (2005) also reported similar positive results.

Nevertheless, human procurement have already been done for well, yet they still keep a problem in executing their jobs because of still lack competencies so, hence they need to develop their abilities. The possession of competencies by the employees would contribute them to learn and build a supportive business environment and to increase higher productivity of organization. The human resource used significantly as a prime mover to other resources and has a strategic position that crucially contributes to busines performance as the competitive advantage, Wright et al., (2005). As when employees would be more developed, they would be more satisfied with the job, more committed with the job and the performance would be increased. When employee performance would increase, this will lead to the organization effectiveness, Champathes,(2006). Therefore, some organizations propose to optimize employee performance in providing optimal contribution, among others through activites of training and development programmes.

Some reseach has been extensively proved by some researcher concerning with the effect of employee development on performance in the recent past. Ebimobowei, Feli and Wisdom (2012) examined human resource development on the performance of public sector accountants in Nigeria. Khan,(2010), studied the effects of human resource development practices on organizational performance in oil and gas industry in Pakistan, and the others are Boadu,at,al (2014), Quartey,(2012), Esia-Donkoh, (2013) and Akuoko,(2012) have already studied it. All the researchers have already proved that human resource development have a positive and significant impact on employees performance which have an implication to the organization performance.

In global business environment recently, Intellectual Capital (IC) has been viewed as a significant subject for either academicians or practitioners. Hence, IC became a major factor for an organization for achieving productivity, efficiency, and success, Chen FC, (2014). In this respect, intellectual capital refers to the integration of each intangible knowledge resources, including individual and organizational knowledge and capabilities and which leads organizational competitive advantage, Su HY, (2014) and Chen FC, et,al, (2014).

At a glance, substantial studies were executed on intellectual capital and its implications on either employee or organization performance were widely covered and obviously, as C. Taleghani et. al. (2011) showed: There are significant relationships between dimensions of IC (human capital, social capital and relation capital) with productivity of Guilan Province. Uadiale and Uwuigbe (2011) indicated: IC has a positive and significant relationship with the performance of business organizations in Nigeria. Djilali et. al. (2012) found, three types of IC together are associated with increase business performance of Algerian firm. Chang and Lee (2012) indicated: A significantly interactive influence of IC upon the organizational performance of Taiwan-listed info-electronics companies.

Zulmiati (2012) proved: Not all of IC components have significant effect on performance. Saeedi et. al. (2012a) concluded: IC components,(relation capital and human capital were having more powerful effect on performance than other variables. Agoston and Dima (2012) concluded: Organizational IC directly and positive related to the competitiveness level and the overall performance.

Based on finding results of former researchers mentioned above, the researcher try to make a researh study at Indonesian Aerospace Industries (Iae) where it is recently faced some phenomenom problem, as : high turn over, late of time delivery product to customers, high rejected product (components), unsmooth work coordination among functions at internal organization.

The purpose of this study is to analysis human procurement and development impact on intellectual capital and Its Implication on Employees Performance at Iae.

\section{Review of Literature \\ Human Procurement}

Human resources procurement is the first operational activities of human resources management which has a relationship activities with processing to get the right people, place and right job. According to Wahyudi (2010:12) that procurement is the process of getting employees throught recruiting, selecting, placing and orienting that comply with organization requirement (the right man in the right place). Procurement is the process of recruiting, selecting, placing and orienting to get the best peoples which could fulfill organization goal Hasibuan ( 2013), and The quality of the human resource the firm has heavily depends on the effectiveness of these two functions (recruiting and selection), Gamage,(2014). Recruiting and selecting the wrong candidates who are not capable come with a huge negative cost which businesses cannot afford. Thus, the overall aim of human procurement( recruitment and selection ) within the organization is to obtain the number and quality of employees that are required to satisfy the strategic objectives of the organization, at minimal cost, Ofori \& Aryeetey, (2011). Actually, the main purpose of recruitment is to create a pool of suitably qualified candidates to enable the selection of the best candidates for the organization, by attracting more and more employees to apply in the organization 
whereas the basic purpose of selection process is to choose the right candidate to fill the various positions in the organization, Gamage, (2014).

Inspite of many distinction definition of human procurement from experts, however it could be concluded that it is an activities to get the best candidates either quantity or quality as required through recruiting,selection,orientation and replacement process in order to achieve an organization objective effectively and efficiently

\section{Development (Training and Education)}

According to Saraswathi (2010), human resource development in organizational context is a process by which the employees of an organization are aided in planning a way to obtain or hone capabilities required to perform various functions associated with their present or expected functional roles; develop their general capabilities as individuals and discover and exploit their own inherent potentials for their own, and, or organizational development processes; develop an organizational culture in which supervisor-subordinate relationship is positive or strong; teamwork and collaborations among sub-units are strong and contribute to the professional well-being, motivation and the pride of employees. Armstrong (2009) clearly stated in his book that organizations could benefit from development through winning the "heart and minds of" their employees to get them to identify with the organization, to exert themselves more on its behalf and to remain with the organization.

The purpose of human development activities are to minimize loss of performance, improve productivity and flexibility of labours, raise employees commitment, and reducing turn over and absent (Schuler dalam Sudayat, 2009). Human development is one of management plan effort to improve employees competency and organization performance through training and education, also career development program,Mondy and Noe, (2005).

Training is imparting a specific skill to do a particular job while education deals with general enhancement and growth of individual skill and abilities through conscious and unconscious learning, Cole, (2002) and Sims (2002) emphasizes that training focuses on present jobs while education prepares employees for possible future jobs. Moreover the purpose of training is to improve employees capabilities, to reduce time study for new employees, to solve operational problem, to prepare employees promotion, to provide employees orientation closely with organization (Carrell \& Kuzmits, dalam Ulvah,2011),

\section{Intellectual Capital Based Information Technology}

A lot of organizations lean recently with intangible asset as a sustainable competitive advantage in running its business. IC is the most important organizational asset for all organizations, whether private or public, profitable or nonprofitable organizations. It can also be concluded that all organizations what ever of their business, they should measure, evaluate, manage and develop their IC, in order to have a sustain for long term survive. Goh (2005) defines intellectual capital as an intangible asset that includes technology, customer information, brand name, reputation, an organizational culture which is invaluable for the company's competitive advantage. Intellectual capital is applied experience, organizational technology, customer relationships, and skills to create competitive advantages.

Intellectual capital is a portofolio of organization resources strategy that it may an organization creating a sustainable values, Kristandi and Bontis,(2007). Intellectual capital represents a collective of knowledge which attributed to the people, organization routine and a relationship of organization Stewart, (1997); Bontis \& Choo,( 2002); Kong, (2008), Intellectual capital occupied as an important resources needed by organization to expand and get a sustainable competitive advantage in business. Chen, (2008); Kong \& Prior,( 2008); Schiuma \& Lerro, (2008), Intellectual capital is often interpreted as a knowledge resources of employees, customers, and process commonly used by organization to create organization value added. Bukh et al (2005)

Pablos, (2002) and Bontis,(1998), suggested that the intellectual capital was comprised of three main components, namely human capital; structural capital and relational capital. Leslie A. Weatherly,(2003.) There are four interrelated groups of IC: Human capital, Structural capital, Social capital and Customer capital. The subsequent studies argued that human capital could be regarded as the skills, knowledge, and abilities, employees use to accomplish their work and organizational objectives, and thus, it was suggested that intellectual capital consisted of human, social and organizational capitals, Youndt MA, Snell SA,(2004). Garavan and colleagues (2001) has described the concept of human intellectual capital by emphasizing four basic attributes of flexibility and adaptability; individual competencies"; "organizational competencies" and "employability".

Su (2014), has indicated that human capital could be considered as the skills, knowledge, and abilities, employees use to accomplish their work and organizational objectives, as argued by Youndt and Snell (2004). In addition, Youndt and colleagues (2004), suggested that intellectual capital consisted of human, social and organizational capitals. Based on aforementioned framework, it is described that intellectual capital are consist of human, social and structural or organizational capitals. Hence, human intellectual capital in this study will refer to the knowledge, skills and abilities of the employees. 
Despite of many distinction definition of intellectual capital issued by experts, but it could be concluded that intellectual capital is one of most important intangible asset of organization which is represented through a pool of knowledge, skill embodied on employees, customers, organization routine and a relationship of organization, which have a capability to create : efficient, value added, profit and provides a competitive adavantage for organization.

\section{Performance}

Many researchers focused on productivity of workers highlighted, the fact proved that employees who keep the appropriate job will deliver job result on time and higher job performance, and thus supreme job retention, than those who are not satisfiied with their jobs. Moreover, it will make the employees demotivation to provide high performance and it is more likely to turnover. Employee performance is higher in happy and satisfied workers and the management find it easy to motivate high performers to attain firm targets, Kinicki and Kreitner, (2007). The employee could be only satisfied when they feel themselves competent to perform their jobs, which is achieved through better human procurement and development programs.

According to Armstrong and Baron, (2013 ) Performance is the result of jobs that provides a strong relationship with goal strategy of organization, customer satisfaction,and giving of economic contribution. Colquitt, LePine, \& Wesson, (2011) stated that Performance is value of employees behavior that provides contribution, either positive or negative to achieve organization objectives. Meanwhile, Cascio,(2013) expressed that Performance is a way to ascertain that individual or group know what demand expected from him or them, and they focus on effective performance by keeping eyes on : objective, dimension,and appraisal. Gibson, Ivancevich (2012) told that Performance is the outcome of job which is related to the organization goal, like : quality, efficiency and effectivity.

The purpose of establish performance is to achieve effectivity of organization goal, where it must be : occupied important, clear, able to be measured and fixed with time, special recorded, in line with organization strategy, supported by reward (Harvard Business Essential, 2006). Performance has seven indicators, namely : Facilities, Competency, Opportunity, Standard, Feedback, Motive, and Objective. Both of seven indicators, motive and objective are more important. Performance is determined by objective and to achieve it, necessary a motive, without it impossible to bring into reality, (Hersey dan Johson dalam Wibowo, 2014).

\section{Relationship between Human Procurement, Development with Intellectual Capital Based Information Technology.}

In global business environment recently, Intellectual Capital (IC) has been viewed as a significant subject for either academicians or practitioners. It is mentioned that this important driver comes from various challenges of the knowledge-based environment which motivate the organizations to highly invest in IC, Goh PC, Lim KP. (2004). Hence, IC became a major factor for an organization for achieving productivity, efficiency, and success, Chen FC, (2014).

Procurement is the process of recruiting, selecting, placing and orienting to get the best peoples which could fulfill organization goal Hasibuan (2013), the overall aim of human procurement( recruitment and selection ) within the organization is to obtain the number and quality of employees that are required to satisfy the strategic objectives of the organization, at minimal cost, Ofori \& Aryeetey, (2011).

According to Saraswathi (2010), human resource development in organizational context is a process by which the employees of an organization are aided in planning a way to obtain or hone capabilities required to perform various functions associated with their present or expected functional roles; develop their general capabilities as individuals and discover and exploit their own inherent potentials for their own, and, or organizational development processes; develop an organizational culture in which supervisor-subordinate relationship is positive or strong; teamwork and collaborations among sub-units are strong and contribute to the professional well-being, motivation and the pride of employees.

From statements of experts mentioned above, either human procurement or development variabels, both of them focus on achievement of organization objectives or goal. Furthermore, It is reinforced by some researchers finding, as : Chao Ying Lee (2012) conducted the research at Australia Biotechnology Industries reveals that the human procurement components (recruitment and selection) have a significant effect (standard beta=.237, p<.01) on intellectual capital organization level (human, structure and social capital), and that human resources components (training \& development) has a significantly effect (standar beta= .240, p<.01) on intellectual capital (human, structure dan social capital).

\section{Relationship between Human Procurement with Intellectual Capital Based IT}

Human procurement activities are focused on getting right people, in right place, and at right time also right skill with purposing to reach business objectives. Kleiman, (2003). Intellectual capital is a way to achieve and gain the competitive position by utilizing a unique combination of human, structural and relational capital. Khandekar and Sharma (2005), indicates the focus on intellectual capital is a means of both maintaining 
competitive advantage and improving the odds of survival in today's business world. The essential of mind is intellectual capital ( people and systems) which adhere to human capital ( knowledge, skill and capability), social capital (relation values among peolple in organization) and organisational or structural capital ( process and organization routinized ) Wright et al.,(2001). Intellectual capital specifically consisted on three kinds of capital, namely : human, social, structural or organizational capital,Sullivan,( 2000). From some statement mentioned above, there are some evidence that reinforced by some reseachers, as : Chao Ying Lee (2012) conducted the research at Australia Biotechnology Industries reveals that the human procurement components (recruitment and selection) have a significant effect (standard beta=.237, $\mathrm{p}<.01$ ) on intellectual capital organization level (human, structure and social capital), and Ajat Sudrajat (2009) also executed a reseach at telkom institute of training and education center declared that there are a significant relation between procurement components (recruitment and selection) and intellectual capital with F score $(33,034$.) > F tabel $(3,29)$.

\section{Relationship between Human Development with Intellectual Capital Based IT}

Human development is one of management plan resposibilities and conducted continously to increase employees and organization competencies through training,education and career development, Mondy \& Noe, (2005). Human development executed by organization through training activities will be able to influnce employee attitude or behavior and their capablities, which have implication on improvement employees performance and farther it could make an alteration for organization, Satterfield and Hughes (2007).

The capabilities of employees seem tobe intellectual capital which has a value for organization, and intellectual capital approved as an important resources that organization expected to develop and have a business sustainable competitive advantage Chen, (2008); Kong \& Prior, (2008); Schiuma \& Lerro,( 2008).

These statements reinforced by finding research of Chao Ying Lee (2012) at Australian Biotechnology Industries, expalined that human resources components (training \& development) has a significantly effect (standar beta $=.240, \mathrm{p}<.01$ ) on intellectual capital (human, structure dan social capital), and also Jyotirmayee and Mishra (2010) researched on departement of business administration at Utkal University Vanivihar, Bhubaneswar, Orissa, India, declared that configuration development of human resources practices has a positive effect on intellectual capital (human capital) with $\mathrm{R}^{2}=0.776$, and finding Mohamad B F dan Omid Baharestan (2014) researched at management department of University of Isfahan, Isfahan, Iran clarified that human resources management (development) has a significantly effect (path coefficient :0.782, t-value : 38.908) on intellectual capital.

\section{Relationship between Human Procurement with Employee Performance}

Throught procurement function conducted correctly will deliver good employees that have knowledge, skill and capablities attractiveness, in other word, have a great competencies. Robin Stuart- Kottze, (2006) said that high performance is the result of doing something correctly at right time, that statement strengthened by research of Yadollah Rajaei (2015) concerning with relation between intellectual capital on employees performance (case study at Abhar Islamic Azad University, Iran). The finding based on level influence of intellectual capital components, are : first structural capital, humal and relation capital on employees performance. Teresia Kavoo (2013) study about influence of procurement ( placement) on employees performance at Chandaria School of Business United States International University of Nairobi, Kenya, The finding, there is strong and positive influence between employee placement practice on employees performance.

\section{Relationship between Human Development with Employee Performance}

Armstrong and Baron, (2013 ) declared that Performance is the result of jobs that provides a strong relationship with goal strategy of organization, customer satisfaction,and giving of economic contribution. Colquitt, LePine, \& Wesson, (2011) stated that Performance is value of employees behavior that provides contribution, either positive or negative to achieve organization objectives. Gibson, Ivancevich (2012) told that Performance is the outcome of job which is related to the organization goal, like : quality, efficiency and effectivity.

Human development is one of management plan effort to improve employees competency and organization performance through training and education, also career development program,Mondy and Noe, (2005). when employees would be more developed, they would be more satisfied with the job, more committed with the job and the performance would be increased. When employee performance would increase, this will lead to the organization effectiveness, Champathes,(2006). Therefor, some organizations propose to optimize employee performance in providing optimal contribution, among others through activites of training and development programmes

The statement mentioned above strengthened by result finding by Philipina, A.(2016) at Private Tertiary Institution in Ghana, stated that there is positive impact of human development on employees performance $\left(\mathrm{R}^{2}=\right.$ 83.33\%) after attended training.and research finding by Chaturvedi B.(2015) at selected public sector organization in India, asserted that there is disimilarity significant at performance level, before $(3,95)$ and after $(4,22)$ training. 


\section{Relationship between Human Procurement, Development on Employees Performance Throught Intellectual Capital.}

Human procurement has purposed to get the best candidate either quantity or quality as organization requirement which is conducted throught recruitment, selection, orientation and placement process, in order to establish effectivity and efficiency in supporting of organization goal, and Human development is one of management plan effort to improve employees competency and organization performance through training and education, also career development program,Mondy and Noe, (2005). when employees would be more developed, they would be more satisfied with the job, more committed with the job and the performance would be increased, meanwhile intellectual capital is the most important intangible asset of organization which is a representative of knowledge, skill collective attributed to the employees, routine organization activities and work relation in organization and has capability to create effeciency, value added and profit include competitive advantage of organization. Employee performance is one of the most impact factor on organization performance. The organization achievement understood the importance of human resources as a critical factor that has direct impact and contribution on performance Al-Qudah, (2014). Based on statement above, the third of variables have a correlation to the organization business superiority. Ebimobowei, Feli and Wisdom (2012) examined human resource development on the performance of public sector accountants in Nigeria. Khan,(2010), studied the effects of human resource development practices on organizational performance in oil and gas industry in Pakistan and Teresia Kavoo (2013) study about influence of procurement ( placement) on employees performance at Chandaria School of Business United States International University of Nairobi, Kenya, The finding, there is strong and positive influence between employee placement practice on employees performance.

\section{Relationship between Intellectual Capital with Employee Performance}

Knowledge-based company is a company consist of knowledge, skill and capablities communities. This company characteristic tends to focus on knowledge for its competitiveness throught intellectual capital investment. Intellectual capital itself is knowledge source in the form of employee, customer, process or technology used by company to improvise company values, Bukh, et.al, (2005). Performance consist of two form, are : employees performance and organization performance, employee performance is the job result of quality and quantity employee based on job standard references meanwhile, organization performance includes a unification of employee and teams performance Mangkunegara, (2004). Based on theory mentioned above, there are strongth relationship between intellectual capital with employees performance.The evidence of that statement reinforced by Yadollah Rajaei reseach (2015) conducted at Abhar Islamic Azad University, Iran, concerning with relation of intellectual capital on employee performance, the finding based on components impact levels of intellectual capital, are : first structural followed humal and relation capital on performance. Seçil Tastan (2015) conducted a research at Marmara Univ. Istanbul, Turkey \& Payam Noor University Tehran, Iran about relevance between intellectual capital and employees performance measured by different constructs of employees behaviour role either in or out of office. The finding There are positive impact and significant between intellectual capital ( social, structure, and human capitals) on employees performance either in or out of office. Wael Sh. Basri reseach (2015) conducted on commercial bank employees at north regions of Saudi Arabia, and the result, there are positive relation from company policy on employees performance which is tied by intellectual capital, the finding showed by t score component of intellectual capital (human, structure and relation capital) respectivelly, are (6.57), (4.34), (5.53) throught statistical significance $(0.00)$ at significant degree $(\alpha \leq 0.05)$.

\subsection{Reseach Hypothesis}

- Hypothesis 1

Human Procurement and Development have positive impact on Intellectual Capital.

- Hypothesis 2

Human Procurement has positive impact on Intellectual Capital.

- Hypothesis 3

Human Development has positive impact on Intellectual Capital.

- Hypothesis 4

Human Procurement and Development have positive impact on Employees Performance Through Intellectual Capital.

- Hypothesis 5

Human Procurement has positive impact on Employees Performance

- Hypothesis 6

Human Development has positive impact on Employees Performance .

- Hypothesis 7

Intellectual Capital has positive impact on Employee Performance 


\subsection{Reseach Framework}

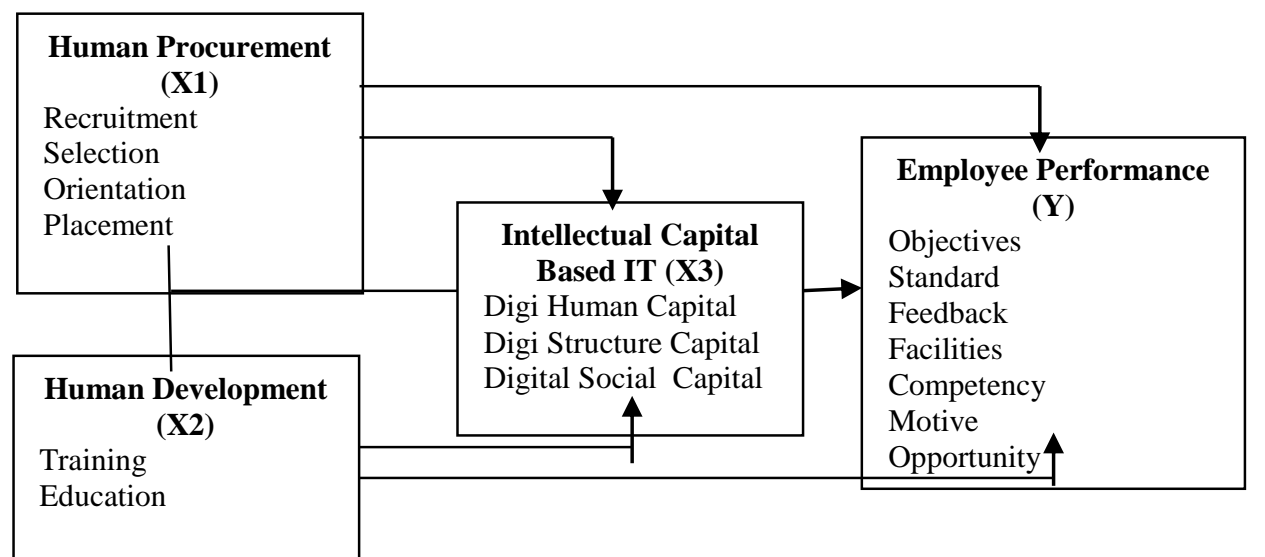

Fig. 1. Theoretical Framework

The Methodology Research

\section{Questionnaire Survey}

This research useds a questionaire survey to collect data and analysis the association between Human Procurement and Development on Intellectual Capital and Its Implication on Employees Performance. The sample size minimum level was determined as 303 employees from 1245 employees core knowledge worker (Aircraft designer, engineer, instructure, production technician dan aircraft maintenance mechanics) Iae, based on Slovin formula.

From 315 questionnaires were distributed among respondents with convenient sampling and 302 questionnaires were returned.

\section{Data Analysis}

In processing and analysing datas used a Structural Equation Modeling (SEM)) with a helping AMOS 20.00, and SPSS Software.

\section{Hypothesis Test}

Normalitas data

Evaluation of normality data conducted with using a criteria critical ration skewness value \pm 2.58 at significant level 0,01 . The result of normality data,as stated on tabel 1

Tabel 1

Normalitas Data

\begin{tabular}{|l|rrrrrr|}
\hline Variable & min & max & skew & c.r. & kurtosis & c.r. \\
\hline y10 & 1,000 & 5,000 &,- 625 & $-4,443$ & 1,313 & 4,667 \\
y9 & 1,000 & 5,000 &,- 281 & $-1,997$ &, 391 & 1,388 \\
y8 & 1,000 & 5,000 & $-2,161$ & $-15,356$ & 4,958 & 17,616 \\
y7 & 1,000 & 5,000 &,- 743 & $-5,281$ & 1,059 & 3,762 \\
y6 & 1,000 & 5,000 & $-1,596$ & $-11,345$ & 3,047 & 10,828 \\
y5 & 1,000 & 5,000 & $-1,506$ & $-10,703$ & 2,729 & 9,697 \\
y4 & 1,000 & 5,000 & $-1,626$ & $-11,555$ & 3,711 & 13,188 \\
y3 & 1,000 & 5,000 & $-1,677$ & $-11,918$ & 2,977 & 10,577 \\
y2 & 1,000 & 5,000 & $-1,339$ & $-9,516$ & 2,059 & 7,315 \\
y1 & 1,000 & 5,000 & $-1,474$ & $-10,475$ & 2,562 & 9,103 \\
x5 & 1,000 & 5,000 & $-1,427$ & $-10,138$ & 2,267 & 8,055 \\
x6 & 1,000 & 5,000 & $-1,727$ & $-12,276$ & 2,783 & 9,887 \\
x1 & 1,000 & 5,000 &,- 887 & $-6,301$ & 1,584 & 5,628 \\
x2 & 1,000 & 5,000 &,- 939 & $-6,670$ & 1,466 & 5,211 \\
\hline
\end{tabular}




\begin{tabular}{|l|rrrrrr|}
\hline Variable & min & max & skew & c.r. & kurtosis & c.r. \\
\hline x3 & 1,000 & 5,000 & $-1,671$ & $-11,877$ & 3,138 & 11,149 \\
x4 & 1,000 & 5,000 & $-1,338$ & $-9,511$ & 2,223 & 7,899 \\
Multivariate & & & & & 65,693 & 23,823 \\
\hline
\end{tabular}

Sources : Result of Data processing

The value of critical ratio skewness for all indiators are above $\pm 2,58$. It proves that all indicators are abnormally distribution. Normalitas multivariate test provides a value $: 28,917$, it shows that as multivariate is abnormally distribution as weii.

\section{Outlier Test}

Test of multivariate outlier conducted with keeping eyes on mahalanobis distance value. The criteria used is Chi-squares value at degree of freedom (df) 98 at significant level : p <0.05. Here it is the result test of outliers data on tabel 2

Tabel 2

Outliers Data

\begin{tabular}{|c|c|c|}
\hline \multicolumn{3}{|c|}{ Mahalanobis Distance (d2) } \\
\hline Maximum. & Minimum. & $\chi^{2}$ \\
\hline 71.031 & 17,079 & 76,163 \\
\hline
\end{tabular}

Sources : Result of Data processing

As showed, on tabel 2, it is ascertainable that mahalanobis distance value is below 76,163 , it could be concluded that there is no outlier on data.

\section{Test Result of Overall Model Fit}

This test is executed to evaluate generally Goodness of Fit $(\mathrm{GoF})$ between data and model. Test result of the Overall Model Fit as describe on tabel 1.

Tabel 3

Test of Research Model

\begin{tabular}{cccc}
\hline $\begin{array}{c}\text { Goodness of Fit } \\
\text { Dimention }\end{array}$ & Test Result & Cut Off Value & Remark \\
\hline Chi-Square $(\mathrm{df}=98)$ & 119.349 & $\chi^{2}$ hit $<\chi^{2}$ Tabel $(122.63)$ & Fit \\
P-value & 0.070 & $\geq 0.05$ & Fit \\
RMSEA & 0.027 & $\leq 0.08$ & Fit \\
TLI & 0.989 & $\geq 0.90$ & Fit \\
CFI & 0.991 & $\geq 0.90$ & Fit \\
GFI & 0.954 & $\geq 0.90$ & Fit \\
AGFI & 0.938 & $\geq 0.90$ & Fit \\
\hline
\end{tabular}

Sources : Result of Data processing

Based on tabel mention above, all Goodness-of-Fit dimention are bigger than cut-off value, it means that all is in fine condition or fit as requirement (Malhotra 2010:733). With refers to mention condition could be concluded that research model at Structural Equation Model (SEM) fits. 


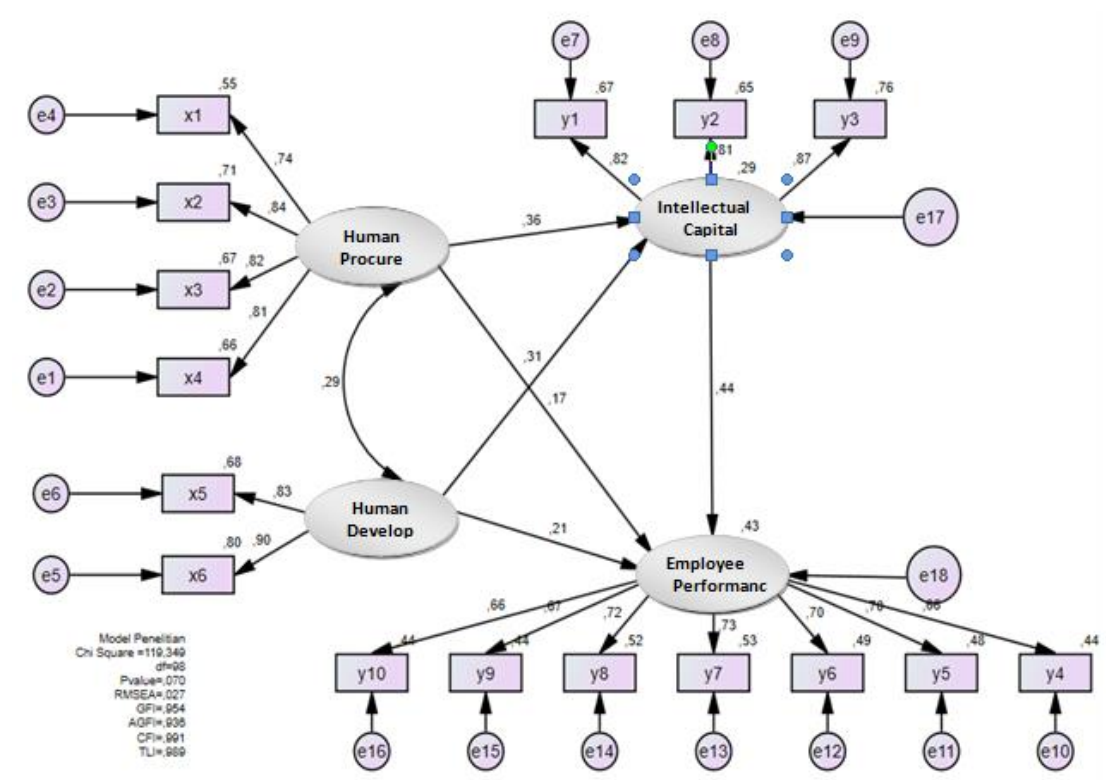

Fig.2 Test Result Model of Path Diagram

\section{Structural Model Fit}

Analysis of structural model has relationship with evaluation on parameters which Indicates causal relationship or effect of one latent variabel toward other latent variabel.

Tabel 4

Resume of Estimation Result of Structural Model Parameter

\begin{tabular}{|c|c|c|c|c|c|c|c|c|}
\hline & & & Esti & ate & & & & \\
\hline & ariab & & RW & SRW & S.E. & C.R. & $\mathbf{P}$ & $\mathbf{R 2}$ \\
\hline $\begin{array}{c}\text { Intellectual } \\
\text { Capital }\end{array}$ & $<---$ & $\begin{array}{c}\text { Human } \\
\text { Procurement }\end{array}$ & 0,334 & 0,358 & 0,06 & 5,577 & $* * *$ & \\
\hline $\begin{array}{c}\text { Intellectual } \\
\text { Capital }\end{array}$ & $<---$ & $\begin{array}{c}\text { Human } \\
\text { Development }\end{array}$ & 0,263 & 0,307 & 0,056 & 4,704 & $* * *$ & $\mathbf{0 , 2 8 7}$ \\
\hline $\begin{array}{c}\text { Employee } \\
\text { Performance }\end{array}$ & $<---$ & $\begin{array}{l}\text { Intellectual } \\
\text { Capital }\end{array}$ & 0,362 & 0,443 & 0,062 & 5,892 & $* * *$ & \\
\hline $\begin{array}{c}\text { Employee } \\
\text { Performance }\end{array}$ & $<---$ & $\begin{array}{c}\text { Human } \\
\text { Procurement }\end{array}$ & 0,127 & 0,167 & 0,048 & 2,633 & 0,008 & 0,432 \\
\hline $\begin{array}{c}\text { Employee } \\
\text { Performance }\end{array}$ & $<---$ & $\begin{array}{c}\text { Human } \\
\text { Development }\end{array}$ & 0,147 & 0,211 & 0,045 & 3,259 & 0,001 & \\
\hline
\end{tabular}

Sources : Result of Data processing

\section{Finding and Discussion}

Hypothesis 1 Human Procurement and Development have positive impact on Intellectual Capital Based IT.

The result indicates that path coeficient value $\left(\mathrm{R}^{2}\right)$ is $0.287>0$, therefore human procurement and development have simultanously impact on intellectual capital, where the value of variabel impact is $28 \%$.

This finding result is the same as Chao Ying Lee (2012) executed at Australia Biotechnology Industries reveals that the human procurement components (recruitment and selection) have a significant effect (standard beta $=.237, \mathrm{p}<.01$ ) on intellectual capital organization level (human, structure and social capital), and that human resources components (training \& development) has a significantly effect (standar beta $=.240, \mathrm{p}<.01)$ on intellectual capital (human, structure dan social capital). 


\section{Hypothesis 2 :Human Procurement has positive impact on Intellectual Capital Based IT}

The result indicates that path coeficient value $(\gamma 1)$ is 0.358 with $\mathrm{p}$-value $<0.05$, therefore path coeficient significant and hypothesis accepted, it means that human procurement has direct impact on intellectual capital with coeficient value is 0,358 or $12,81 \%$. This finding result is the same as Ajat Sudrajat (2009) carried out at telkom institute of training and education center declared that there are a significant relation between human procurement (recruitment and selection) and intellectual capital with F score $(33,034$.) $>$ F tabel $(3,29)$.

\section{Hypothesis 3 : Human Development have positive impact on Intellectual Capital Based IT}

The result indicates that path coeficient value $(\gamma 1)$ is 0.307 with $\mathrm{p}$-value $<0.05$, therefore path coeficient significant and hypothesis accepted, it means that human development has direct impact on intellectual capital with coeficient value is 0,307 or $9.42 \%$

This finding result is the same as Jyotirmayee and Mishra (2010) researched on departement of business administration at Utkal University Vanivihar, Bhubaneswar, Orissa, India, declared that configuration development of human resources practices has a positive effect on intellectual capital (human capital) with $\mathrm{R}^{2}$ $=0.776$.

\section{Hypothesis 4 : Human Procurement and Development have positive impact on Employees Performance Through Intellectual Capital Based IT}

The result indicates that path coeficient value $\left(\mathrm{R}^{2}\right)$ is $0.432>0$, therefore human procurement and development have simultanously impact on employee performance through intellectual, where variabel impact value is $43,2 \%$.

\section{Hypothesis 5 : Human Procurement has positive impact on Employees Performance.}

The result indicates that path coeficient value $(\gamma 1)$ is 0.167 with $\mathrm{p}$-value $<0.05$, therefore path coeficient significant and hypothesis accepted, it means that human procurement has direct impact on employee performance with coeficient value is 0,167 or $2.78 \%$.

This finding result is the same as Yadollah Rajaei (2015) studied at Abhar Islamic Azad University, Iran, research finding based on impact of intellectual capital dimentions level, are : first structural capital, humal and relation capital on employees performance.

\section{Hypothesis 6 : Human Development has positive impact on Employees Performance}

The result indicates that path coeficient value $(\gamma 1)$ is 0.211 with p-value $<0.05$, therefore path coeficient significant and hypothesis accepted, it means that human development has direct impact on employee performance with coeficient value is 0,211 or $4.45 \%$. This finding result is the same as Philipina, A.(2016) conducted on Private Tertiary Institution in Ghana, stated that there is positive impact of human development on employees performance $\left(\mathrm{R}^{2}=83.33 \%\right)$ after attended training.

\section{Hypothesis 7 : Intellectual Capital Based IT has positive impact on Employee Performance}

The result indicates that path coeficient value $(\gamma 1)$ is 0.443 with $\mathrm{p}$-value $<0.05$, therefore path coeficient significant and hypothesis accepted, it means that intellectual capital has direct impact on employee performance with coeficient value is 0,443 or $19.62 \%$.

This finding result is the same as. Wael Sh. Basri reseach (2015) conducted on commercial bank employees at north regions of Saudi Arabia, and the result, there are positive relation between company policy and employees performance which is tied by intellectual capital, the finding stated that $\mathrm{t}$ score dimentions of intellectual capital (human, structure and relation capital) has respectively value, namely ;(6.57), (4.34), (5.53) throught statistical significance $(0.00)$ at significant degree $(\alpha \leq 0.05)$.

\section{Discussion}

Based on the results of the previous review, there are three kinds of variabel used to improve employee performance as described in the related work section, namely, human procurement, human development and intellectual capital, where all variabels have a positive and significant impact either direct or indirect on employees performance. From the result of data processing on human procurement and human development have positive direct impact on employee performance with value : $2,78 \%$ and $4.45 \%$ (very low), meanwhile indirect impact on employee performance through intellectual capital have value : 43,3\% means bigger than others.

Meanwhile human procurement executed by company, according to employees perception are unsatisfaction which is proved with score value : $67,91 \%$, from minimum standard $70 \%$ and has a profile low. It means recruiting,selection and placement new employees are not in line with job qualification or requirement. For human development executed by company, according to employees perception are quite satisfaction which is proved with score value : $70,83 \%$, and has a profile high. It means that all employees agree with human 
development program because will improve either employees or company productivity. For intellectual capital (human,structure and social capital), employees have a good response which is proved score value 72,29\% and has a profile high.It means that the existences of sistem and procedure, internal networking and human have capabilities to finish dan problem solving of work but it needs improvement. For employee performance which is percepted by employee unsatisfaction with score value $65,81 \%$ and have a profile low. It means that the achievemet of job target did not agree with plan.

\section{Recomendation}

Iae management should have a transparant and selective human procurement system which is oriented to the job qualificatin required and right placement agree with their skill. To apply human development system which is needed by employees to increase their skill and improve job productivity and could solve their job problem. Iae management should also issue a flexibility of system and procedure which provided for either internal or external in order to accelerate services. Iae management should have a better reward and career path system for employees as reference to improve their motivation and performance.

\section{Conclusion}

As long as human procurement and development also intellectual capital based information technology as an important activities for organization to improve employees or organizational performance, they should be kept maintain up date as requirement till, organization could fulfil customer and market demand in order to achieve target as organization plan. They will also become a sustainable competitive advantage for progress business.

\section{Reference}

1. Books

2. Armstrong, M. (2009) Human Resource Management Practice. 11th Edition, Kogan Page Limited, London.

3. Armstrong, dan Baron,(2013), Human Capital Management, Penerbit PPM Jakarta

4. Bontis N,(1998), Intellectual capital: an exploratory study that develops measures and models. Management decision. 36(2):63-76.

5. Cascio, W. F. (2013). Managing Human Resources: Productivity, Quality of Work Life, and Profits (6th Ed.). Boston: McGraw-Hill, Irwin.

6. Champathes, M. R. (2006), Coaching for performance improvement: The coach model. Development and Learning in Organizations, Volume 20, No. 2, pp.17-18.

7. Choo and Bontis,(2002),The Strategic Management of Intellectual Capital and Organization Knowledge, Oxford University Press.

8. Colquitt, LePine, and Wesson,(2011), Organization Behavour, New York McGraw-Hill

9. Cole, G.A. (2002) Personnel and Human Resource Management. 5th Ed., York Publishers, Continuum London.

10. Chen FC, Liu Z, Kweh QL, (2014), Intellectual capital and productivity of Malaysian general insurers. Economic Modelling; 36:413-20.

11. Garavan TN, Morley M, Gunnigle P, Collins E,(2001). Human capital accumulation: the role of human resource development. Journal of European Industrial Training. ; 25(2/3/4):48-68.

12. Gberevbie, D. E. (2008). Staff Recruitment, Retention Strategies and Performance of Selected Public and Private Organizations in Nigeria. Covenant University, College of Business. Ota: Social Science press.

13. Gibson, Ivancevich, Donnelly, dan Konopaske,(2012), Organization, New York McGraw-Hill

14. Hardvard, Business, Essentials, (2006), Performance Management, Boston : Harvard Business School Publishing Corporation.

15. Hasibuan, M. S. P. (2013). Human Resources Management, Revise edition. Bumi Aksara Jakarta

16. Ichniowski, C., \& Shaw, K. (1999). The Effects of Human Resource Management on Economic Performance: An International Comparison of US and Japanese Plants. Management Science, 45 (5), 704- 723.

17. Jyotirmayee C, Dr B. B. Mishra (2010),"Theoretical and Empirical Investigation of Impact of DevelopmentalHR Configuration on Human Capital Management, "Dept of Business Administration, Utkal UniversityVanivihar, Bhubaneswar, Orissa, India.International Business Research Vol. 3, No. 4; October 2010

18. Kinicki, A. and Kreitner, R. (2007),Organizational Behavior, McGraw-Hill, New York, NY.

19. Leslie A. Weatherly,(2003.), SPHR HRContent Expert, Measuring and Managing Human Capital, A Strategic Imperative for $H R$ 
20. Mangkunegara A.A Anwar, Prabu (2004)., Human Resources Management, Remaja Rosdakarya, Bandung.

21. Mondy, and Noe, (2005), Human Resources Management, Ninth edition, by Pearson Education, Inc New Jersey

22. Sang, C. (2005). Relationship between human resource management practices and perception of organizational Taiwan performance, roles of management style, social capital, and culture: Comparison between manufacturing firms in Cambodia and Taiwan. MSc Thesis, National Cheng Kung University, Taiwan.

23. Sullivan, P.H.(2000), Value-driven Intellectual Capital: How to Convert Intangible Corporate Assets into Market Value, John Wiley \& Sons, Toronto.

24. Ulvah, Fitria, (2011), Manajemen Sumber Daya Manusia, Diakses dari www.scribd.com/doc/54057584/MSDM-training pada tanggal 29 Maret 2011

25. Wibowo, (2014), Performance Management, 4th Edition, Published byt PT. Raja Grafindo Persada Jakarta

26. Zheng, Z., \& Hong, T. (2006). Competitive advantage through people.London: Harvard Business School Press.

\section{Journal}

28. Chao Ying Lee (2012), The Impact of Human Resource Configurations on Intellectual

29. Capital in the Australian Biotechnology Industry, Chia Nan University of Pharmacy \&Science, Taiwan.The Journal.

30. Chen, Y. S. (2008). The Positive Effect of Green Intellectual Capital on Competitive Advantages of Firms. Journal of business ethics, 77(3), 271-286.

31. Croucher. (2008). Impact of Human Resource Management in Organisation Performance. Academy of Management Journal, 39 (4), 779-801.

32. Ebimobowei, T. S. Felix, and S. C. Wisdom, (2012) „Human resource development mechanism and the Performance of Public Sector Accountants in Nigeria ". Current Research Journal of Social Science, vol. 4, no. 3: pp: 246-255, 2012

33. F. Boadu, E. Dwomo-Fokuo, J. K. Boakye and C. O. Kwaning,(2014), training and development: a tool for employee performance in the District Assemblies in Ghana "International Journal of Education and Research, vol. 2, no. 5: pp: 513-522.

34. Gamage, A. S. (2014). Recruitment and selection practices in manufacturing SMEs in Japan: An analysis of the link with business performance. Ruhuna Journal of Management and Finance, 1(1), 37-52

35. Heneman, H. G., \& Judge, T. A. (2003). Staffing Organization (4th ed.). Boston: McGraw-Hill, Irwin. Hill, R. E. (1970). New look at employee referrals as a recruitment channel. Personnel Journal, 49, 144 148.

36. Katou, A., \& Budhwar, P. (2006). Human Resource Management Systems on Organizational Performance: A test of mediating model in the Greek manufacturing context. International Journa of Human Resource Management, 17 (7), 1223-1253

37. K. O. Akuoko,(2012),, Training and development and employee performance in district assemblies in Ghana: A study of the Bosomtwe District in the Ashanti Region ", International Journal of Business and Management Studies, vol. 1, no. 1: pp: 321-331.

38. K. Esia-Donkoh, H. Bampoh-Addo and D. Afful,(2013) „Making Employee Training and Development a Tool for Efficiency and Effectiveness in Ghanaian Universities ", Journal of Education and Practice, vol. 4, no. 24: pp: 88-93.

39. Kong E and Prior D (2008), An intellectual capital perspective of competitive advantage in non-profit organizations. International Journal of Non-profit and Voluntary Sector Marketing 13(2), 119-128.

40. Kong E (2008a) The development of strategic management in the nonprofit context: intellectual capital in social service non-profit organizations. International Journal of Management Reviews 10(3), 281-299.

41. Mohamad B F, Omid Baharestan (2014), 'Investigating the Effect of Human Resources Management and Intellectual Capital on Performance, (Kermanshah Physical Education as a case study) "International Journal of Academic Research in Economics and Management Sciences May 2014, Vol. 3, No. 3 ISSN: 2226-3624.

42. M. A. Khan, (2010) „Effects of human resource management practices on organizational performance: An empirical study of oil and gas industry in Pakistan ". European of Journal of Economics, Finance and Administrative Science, vol. 24: pp: 157-175.

43. Ofori, D., \& Aryeetey, M. (2011). Recruitment and selection practices in small and medium enterprises. International Journal of Business Administration, 2(3):45-60.

44. Pablos PO, (2002), Evidence of intellectual capital measurement from Asia, Europe and the Middle East. Journal of Intellectual Capital. 3(3):287-302. 
45. Philipina, Ampomah (2016), "The Effect of Training and Development on Employee Performance in a Private Tertiary Institution in Ghana" Case Study: Pentecost University College (Puc) Ghana), "Department of Secretaryship and Management Studies, Cape Coast Polytechnic, Ghana.Asian Journal of Social Sciences and Management Studies, ISSN: 2313-740,Vol. 3, No. 1, 29-33 , 2016

46. S. Saraswathi (2010), HRD climate: An empirical study. International Journal of Innovation Management and Technology, vol.1, no 2: pp: 174-179

47. Seçil Tastan,and Seyed Mehdi, Mousavi, Davoudi(2015), "A Research on the Relevance of Intellectual Capital and Employee Job Performance as Measured with Distinct Constructs of In-Role and Extra Role Behaviors, " Marmara University Istanbul, Turkey \& Payam Noor University Tehran, Iran.Indian Journal of Science and Technology, Vol 8(S7), 724-734, April 2015'ISSN (Print) : 0974-6846, ISSN (Online) : 0974-5645

48. Su HY, (2014), Business Ethics and the Development of Intellectual Capital. Journal of Business Ethics ; 119:87-98.

49. S. H. Quartey,(2012),,Effect of employee training on the perceived organisational performance: a case study of the print-media industry in Ghana ", European Journal of Business and Management, vol. 4, no. 15: $p p:$ 77-87,

50. Teresia, Kavoo - Linge, James K, Kiruri (2013)," The Effect of Placement Practices on Employee Performance in Small Service Firms in the Information Technology Sector in Kenya, "Chandaria School of BusinessUnited States International University Nairobi, Kenya.International Journal of Business and Social Science Vol. 4 No. 15 [Special Issue - November 2013]

51. Wael Sh, Basri(2015), The Role of the Intellectual Capital in Raising the Performance of Employees in the Commercial Banks in Saudi Arabia" Case Study in Northern Border Region," Northern Border University, College of Business Administration, ArAr. Saudi Arabia.Asian Journal of Business and Management (ISSN: 2321 - 2802) Volume 03 - Issue 04, August 2015

52. Wright, P. M., \& Boswell, W. R. (2005). Desegregating HRM practices: A Review and synthesis of Micro and Macro Human Resource Management. Journal of Management, 28 (3), 247- 276.

53. Yadollah, Rajaei, Farid Asgari, Roya Shahsavari(2015), "Relation Between Intellectual Capital on Employee Performance, "Case study Abhar Islamic Azad University, Iran.DU Journal, Humanities and Social Sciences April 2015 Vol 8 (4) 4 20-433

54. Youndt MA, Snell SA,(2004), Human resource configurations, intellectual capital, and organizational performance. Journal of Managerial Issues. ; 337-60 